\title{
Integrasi Grafin Oksida Berbasis Larutan sebagai Material Penghantar Lubang pada Sel Surya Hibrid Bulk-Heterojunction (BHJ)
}

\author{
Alfian F. Madsuha*, Nofrijon Sofyan, A.H. Yuwono \\ Department of Metallurgy and Materials Engineering, Universitas Indonesia, Kampus Baru UI, 16424 Depok, Indonesia \\ *Corresponding Author's E-mail: alfian@eng.ui.ac.id
}

\begin{abstract}
Abstrak - Dalam penelitian kali ini, telah didemonstarsikan penggunaan Grafin Oksida (GO) sebagai material pengantar lubang pada sel surya hibrid Bulk-Heterojunction (BHJ). Sebuah metode sederhana digunakan dalam memodifikasi anoda dari sel surya hibrid dengan cara mendeposisi material karbon nano hasil proses larutan diantara kaca transparan indium timah oksida(ITO) dan lapisan fotoaktif. Perngguanan GO ini ditujukan untuk mengganti secara keseluruhan polimer konduktif poly(3,4ethylenedioxythiophene) polystyrene sulfonate (PEDOT:PSS). Dengan penggunaan lapisan GO ini, perbaikan efisiensi konversi energi dari 0,1\% menjadi 1,66 \% dapat dicapai melalu mekanisme penurunan hambatan seri $\left(R_{S}\right)$. Dengan hasil ini $G O$ telah berhasil menunjukkan potensial yang besar untuk digunakan sebagai material pengantar lubang yang efisien pada sel surya hibrid
\end{abstract}

Kata kunci: Grafin, CdSe; Quantum Dots; Bulk heterojunction; Hybrid Solar Cells,

\section{Pendahuluan}

Pada divais sel surya tipe hibrid bulk hetero-junction, antarmuka berupa lapisan penghantar lubang (HTL) yang terletak di antara lapisan fotoaktif dan elektrode memiliki peranan yang sangat penting dalam menentukan efisiensi dan kestabilan.

Poly (3,4-ethylenedioxythiophene):poly(styrenesulfonate) (PEDOT:PSS) merupakan material polimer konduktif yang umum dipakai sebagai lapisan pengantar lubang berupa larutan yang terdeposisi pada lapisan Indium Timah Oksida (ITO), yaitu. Selain memodifikasi fungsi kerja (WF) lapisan anoda sehingga mengurangi hambatan antara Highest Occupied Molecul Orbital (HOMO) dan lapisan fotoaktif, polimer ini akan memperhalus permukaan ITO ${ }^{[1]}$. Namun, antar-muka ITO/PEDOT:PSS juga menjadi sumber ketidakstabilan pada divais ${ }^{[2-4]}$. Beberapa sifat yang tidak diinginkan dari PEDOT:PSS yaitu karakter higroskopi dan asam, yang justru akan mengurangi kinerja polimer ini sebagai HTL [5, 6]. Dalam hal ini, PEDOT yang bersifat higroskopi dapat mengikat air ke dalam lapisan fotoaktif ketika divais terekspos lingkungan yang lembap, sehingga akan berakibat kepada degradasi ${ }^{[7,}{ }^{8]}$. Ditambah lagi, diketahui bahwa ITO sangat sensitif terhadap lingkungan yang bersifat asam, sehingga asam kuat yang berasal dari larutan PSS dari lapisan PEDOT:PSS bisa menimbulkan korosi pada elektroda ITO ${ }^{[9]}$. Oleh karena itu, beberapa usaha telah dilakukan untuk mengatasi masalah ini diantaranya menggunakan material organik dan inorganik yang dapat digunakan sebagai alternatif HTL, diantaranya trifluoropropyltrichlorosilane (TFPS) dan semikonduktor logam oksida $\left.\mathrm{NiO}, \mathrm{MoO}_{3}, \mathrm{~V}_{2} \mathrm{O}_{5}, \mathrm{WO}_{3}\right)^{[10]}$.
Pada perkembangan terbaru, sifat kondutifitas listrik, optoelektronik yang dapat direkayasa, murah dan stabil dalam lingkungan apapun menjadikan material grafin dan turunannya telah menjadi kandidat HTL yang menjanjikan pada sel surya organik (OSCs) ${ }^{[11]}$

Sebagai contoh, lapisan grafin (ketebalan $\sim 10 \mathrm{~nm}$ ) yang didapatkan dari reduksi termal grafit oksida mampu menunjukkan konduktivitas tinggi sekitar $550 \mathrm{~S} / \mathrm{cm}$ dan tranparansi lebih dari $70 \%$ pada rentang $1000 \mathrm{~nm}-3000 \mathrm{~nm}$ [12]. Beberapa kelebihan grafin oksida jika dibandingkan PEDOT:PSS ketika digunakan sebagaian HTL diantaranya, tidak mengkorosi ITO, rekayasa tingkat energi yang lebih mudah sehingga ekstraksi lubang menjadi efisien, dan tingkat transparan yang tinggi. Celah pita yang besar dari GO akan mencegah elektron mengalir ke anoda, sehingga akan menguarangi rekombinasi ${ }^{[10]}$.

Li et al. pertama kali melaporkan penggunaan GO sebagai pengganti PEDOT:PSS untuk aplikasi HTL pada OSC ${ }^{[13]}$. Sejak itu penggunaan GO sebagai aplikasi HTL pada OSC menjadi umum. Namun, sejauh ini penulis belum menemukan pendekatan yang sama pada sel surya hibrid. Salah satu kelamahan GO HTL berbasis larutan adalah sifatnya yang kurang konduktif, menagkibtakan tingginya resistan seri, rendahnyanya fill factor dan berakhir kepada efisiensi (PCE) yang rendah ${ }^{[14]}$. Hal ini disebabkan proses sistesis kimia basah GO yang menggunakan asam kuat, menghasilkan gugus epoksi dan hidroksil pada permukaan $\mathrm{GO}$, yang mengacaukan susunan $\mathrm{sp}^{2}$ yang konduktif, sehingga $\mathrm{GO}$ bersifat insulator ${ }^{[15]}$.

Untuk merestorasi sifat konduktif, produk GO yang disintesi harus direduksi, menghilangkan gugus fungsional oksigen, selain itu reduksi ini akan mengubah fungsi kerja GO itu sendiri [16]. Penelitian ini termovivasi untuk 
menjawab tantangan tersebut, dengan cara menemukan GO HTL berbasis larutan yang cocok untuk sel surya hibrid dengan cara mengganti fungsi PEDOT:PSS dengan GO.

\section{Dasar Teori}

\subsection{Sintesis Grafin Oksida}

Sintesis grafin oksida (GO) sebagai bahan pembuatan elektroda telah berhasil dilaksanakan sebagaimana diperlihatkan pada Gambar 6 di bawah ini. GO disintesis menggunakan metode Hummer dengan beberapa modifikasi. Pada sintesis ini tipikal $1 \mathrm{~g}$ graphite, $46 \mathrm{ml} \mathrm{H}_{2} \mathrm{SO}_{4}$ and $0.5 \mathrm{~g}$ $\mathrm{NaNO}_{3}$ dicampur secara bersamaan dan diaduk pada temperature $35^{\circ} \mathrm{C}$ selama 2 menit. Kemudian larutan diaduk pada lingkungan rendaman es agar mencapai temperatur 0 ${ }^{\circ} \mathrm{C}$ yang biasanya membutuhkan waktu selama 15 menit. Setelah itu $3 \mathrm{~g} \mathrm{KMnO}_{4}$ ditambahkan ke dalam larutan secara perlahan sehingga rekasi eksotermik yang ditimbulkan tidak membuat temperatur melebihi $20^{\circ} \mathrm{C}$. Selanjutnya larutan tetap diaduk selama 6 jam pada temperatur $35^{\circ} \mathrm{C}$. Kemudian $3 \mathrm{~g} \quad \mathrm{KMnO}_{4}$ ditambahkan lagi ke dalam larutan dan pengadukan dilanjutkan selama 12 jam pada temperature 35 ${ }^{\circ} \mathrm{C}$. Tahap berikutnya adalah penambahan $6 \mathrm{ml} \mathrm{H}_{2} \mathrm{O}_{2}$ sedikit demi sedikit dimana temperatur dijaga agar tidak melebihi $80{ }^{\circ} \mathrm{C}$. Penambahan ini bertujuan agar residu $\mathrm{KMnO}_{4}$ dan $\mathrm{MnO}_{2}$ tereduksi menjadi $\mathrm{Mn}^{2+}$ dan larut. Pada tahap ini warna larutan akan berubah dari coklat gelap menjadi kuning terang. Tahap selanjutnya adalah pemisahan GO dari larutan sehingga dapat digunakan untuk berbagai aplikasi. Setelah GO diaduk dengan total durasi selama 18 jam, GO dicuci dengan akuades hingga mencapai $\mathrm{pH}$ netral. Larutan asam yang didapat selama sintesis dibuang kemudian endapan GO dilarutkan dengan akuades. Selanjutnya larutan GO dalam akuades ini kembali dipisahkan menggunakan sentrifus Gemmy PLC-03 pada tabung sentrifus berukuran $15 \mathrm{ml}$ selama 25 menit pada $4000 \mathrm{rpm}$. Setelah disentrifus, endapan grafin oksida dilarutkan di dalam akuades dan disaring menggunakan perangkat vakum filter.

2.2 pembuatan divais sel surya

Divais difabrikasi di atas kaca ITO. Sel surya yang diinvestigasi berbasis konfigurasi HTL ITO/PEDOT:PSS, ITO/rGO/ dan Tanpa HTL. Semikonduktor yang digunakan berupa lapisan komposit fotoaktif kadmium selenide kuantum dots (CdSe) dan Poly[2,6-(4,4-bis-(2-ethylhexyl)4H-cyclopenta[2,1-b;3,4-b']dithiophene)-alt-4,7(2,1,3-

benzothiadiazole)] (PPCPDTBT). Lapisan fotaktif tersebut dideposisi menggunakan metode spin coating

2.3 Characterization

UV-Vis absorption spectrum didapat menggunakan TIDAS $100 \mathrm{~J} \& \mathrm{M}$ diode-array spectrometer. Kuat rapat arus diukur menggunakan komputer yang terkontrol oleh Keithley 2400 source meter dan sun simulator.

\section{Temuan dan Pembahasan}

3.1 Lapisan Elektroda Berbasis Grafin Oksida

Gambar 1 menunjukkan foto SEM dari GO yang dideposisikan di atas ITO. Lembaran GO memiliki ukuran bervariasi dari ratusan $\mathrm{nm}^{2}$ sampai $10 \mu \mathrm{m}^{2}$, dengan rata-rata sebesar $4,3 \mu \mathrm{m}^{2}$.

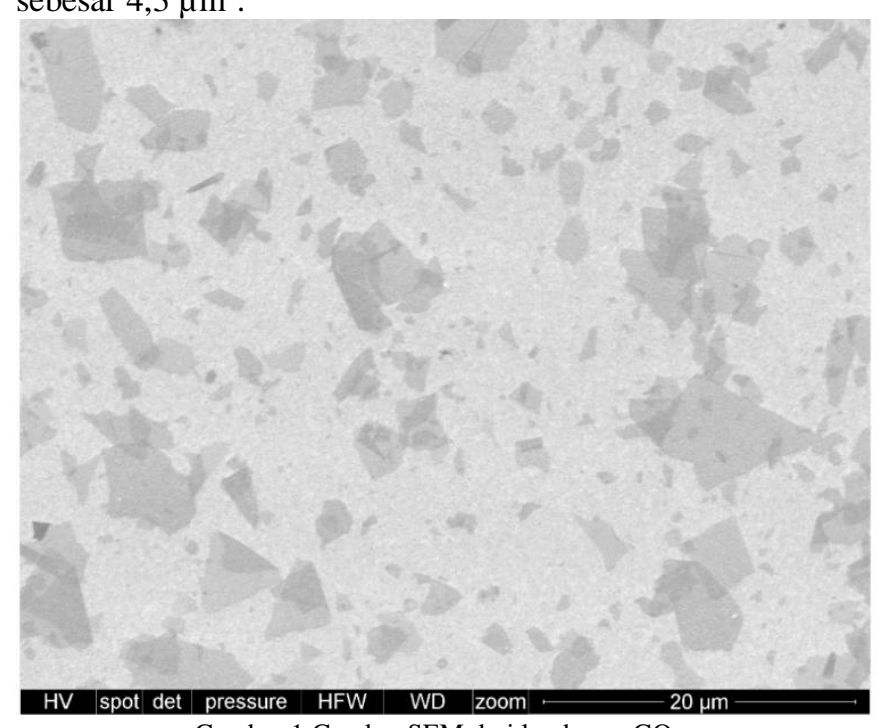

Gambar 1 Gambar SEM dari lembaran GO

Untuk menginvestigasi sifat transport muatan lubang dari GO, lapisan tipis GO dideposisi menggunakan teknik spin coating di atas lapisan ITO. Kemudian, untuk menghilangkan sisa pelarut, lapisan GO tersebut dianil pada $300{ }^{\circ} \mathrm{C}$ selama 1 jam pada kondisi. Perlakuan panas ini akan membuat sebagian GO akan tereduksi, oleh karena itu semua GO lapisan yang digunakan untuk aplikasi sel surya ini disebut juga sebagai GO tereduksi (rGO). Pada Gambar 2, ditampilkan foto AFM beserta profil ketinggian dari lapisan GO dan ITO sendiri. Dapat disimpulkan bahwa permukaan GO memiliki tingkat kekasaran yang lebih kecil dengan ITO sendiri

a
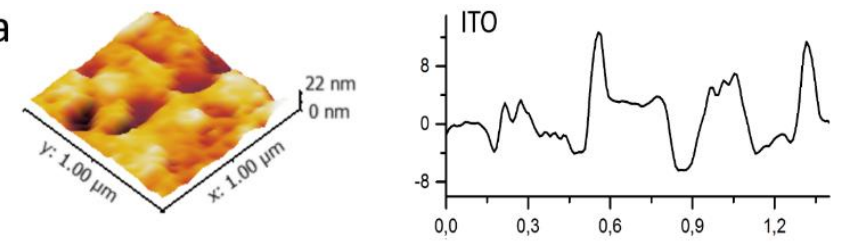

b
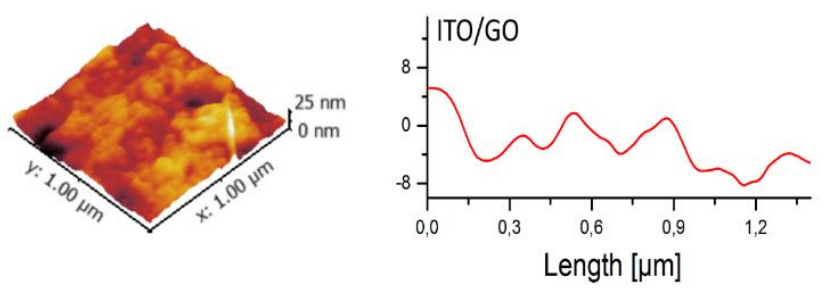

Gambar 2 Foto AFM dan profil ketinggioan dari (a) ITO, (b) ITO/rGO. Lapisan GO dideposisi menggunaan larutan dengan konsentrasi of 1,2 $\mathrm{mg} / \mathrm{mL}$

Selain aspek fungsi kerja yang sesuai, parameter lain yang sangat penting untuk aplikasi lapisan transport lubang adalah transparansi ${ }^{[39]}$. Tranparansi dari lapisan karbon nano sangat penting agar transmisi foton dapat dialirkan ke lapisan fotoaktif dengan efisien. Gambar 3 menampilkan spektra transmisi UV-Vis dari ITO, ITO/PEDOT:PSS dan ITO/GO. Dapat disimpulkan bawah pada rentang $600 \mathrm{~nm}-800 \mathrm{~nm}$, lapisan tipis karbon nano tidak mempengarui transparansi 
secara signifikan, sehingga cahaya masih bisa menjangkau lapisan fotoaktif. Sedangkapn pada gelombang sekitar 650 nm, lapisan PEDOT:PSS mengalami penurunan transmisi $5 \%$, lapisan rGO mengalami penurunan transmisi lebih besar, sebesar $8 \%$. Hal ini mengindikasikan bahwa lapisan GO yang terdeposisi pada ITO ini terdiri dari beberapa lapisan, diketahui bahwa tiap satu lapis grafin akan mengurangi trasnmisi sebesar $2,3 \%{ }^{[17]}$.

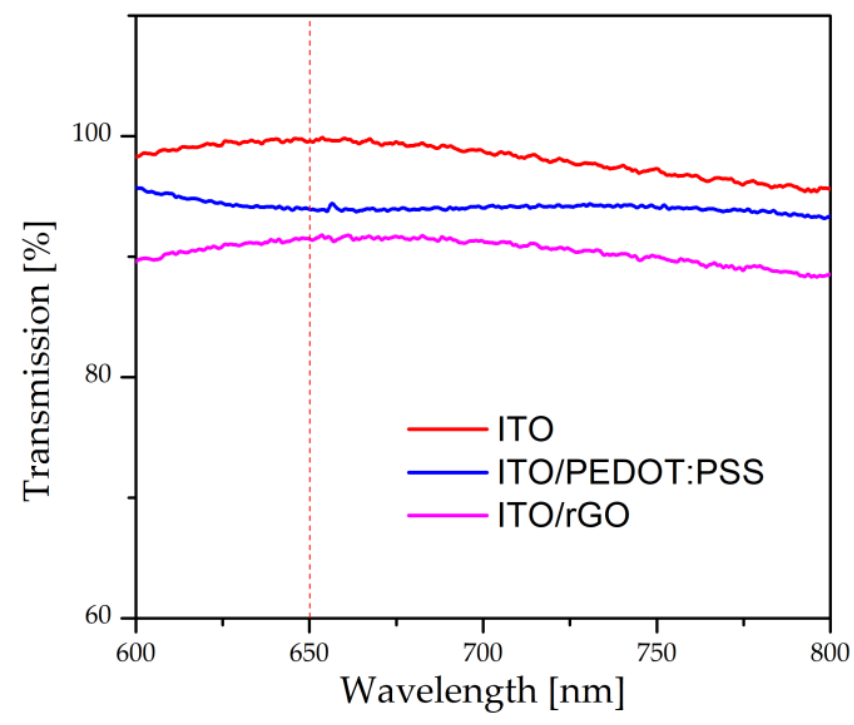

Gambar 3 Transmisi cahaya pada lapisan GO, lapisan PEDOT:PSS dan ITO (yang berlaku sebagai referensi)

3.2 Divais Sel Surya Berbasis Lapisan Elektroda Grafin Oksida

Divais sel surya yang difabrikasi dalam penelitian ini terdiri dari tiga kelompok berdasarkan konfigurasi lapisan transport hole, sebagaimana diperlihatkan pada Gambar 4. Karakteristik kuat rapat arus tegangan ditampilkan pada Gambar 12 dan nilainya dapat dilihat pada Tabel 1.

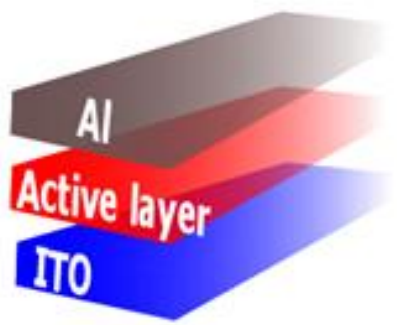

a

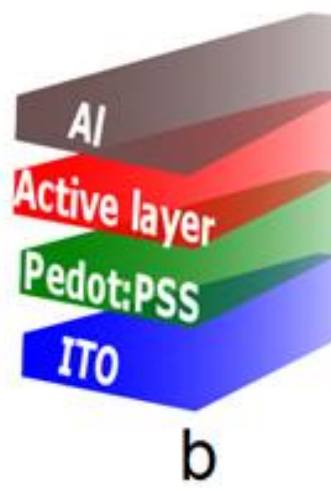

Gambar 4 Ilustrasi skematik dari divais yang difabrikasi berdasarkan konfigurasi transport lubang: (a) tanpa HTL, (b) PEDOT:PSS HTL, and (c) GO HTL

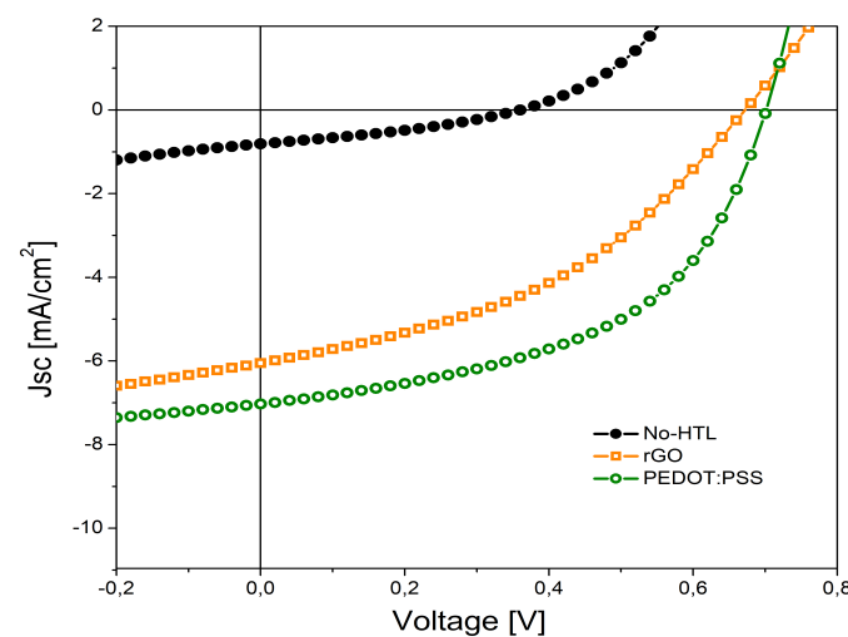

Gambar 5 Kurva J-V curves dari divais berdasarkan konfigurasi HTL

Tabel 1 Rangkuman kinerja divais berdasarkan konfigurasi HTL.

\begin{tabular}{|c|c|c|c|c|c|c|}
\hline HTL & $\operatorname{Voc}[\mathrm{v}]$ & $\mathrm{Jsc}\left[\mathrm{mA}^{\left.-\mathrm{cm}^{2}\right]}\right.$ & $\mathrm{FF}$ & $\mathrm{PCE}[\%]$ & $\begin{array}{c}R_{\text {sh }} \\
{\left[\Omega_{\mathrm{cm}^{2}}\right]}\end{array}$ & $\begin{array}{c}\mathrm{R}_{\mathrm{a}} \\
{\left[\Omega \mathrm{cm}^{2}\right]}\end{array}$ \\
\hline No-HTL & 0.36 & 0.81 & 0.37 & 0.10 & 413.0 & 126.0 \\
\hline EDOT:PSS & 0.70 & 7.03 & 0.51 & 2.50 & 515.5 & 16.3 \\
\hline $\mathrm{GQ}$ & 0.68 & 6.05 & 0.40 & 1.66 & 403.2 & 31.3 \\
\hline
\end{tabular}

Gambar 6 menunjukkan diagram tingkat energi dari ketiga kelompok divais sel surya. Fungsi kinerja (WF) dari ITO dan PEDOTS:PSS berdasarkan literatur masing-masing sebesar 4,7 $\mathrm{eV}^{[18]}$ and 5,0 eV ${ }^{[19]}$. Level HOMO and LUMO dari polimer PCPDTBT masing-masing sebesar $-5,3 \mathrm{eV}$ and $-3,5$ $\mathrm{eV}^{[20]}$. Pita valensi dan konduksi dari semikonduktor CdSe QDs untuk ukuran $6 \mathrm{~nm}$ diperkirakan masing-masing sebesar $-5,59 \mathrm{eV}$ and $-3,62{ }^{[21]}$. Telah dilaporkan juga bahwa perlakuan anil pada GO hingga temperatur $350{ }^{\circ} \mathrm{C}$ akan mengakibatkan WF turun sebesar $0,3 \mathrm{eV}$, sehingga WF dari GO murni yang besaran sekitar 5,0 - 5,1 eV ${ }^{[22]}$; maka akan berubah menjadi sekitar $4,7-4,8 \mathrm{eV}^{[23]}$.

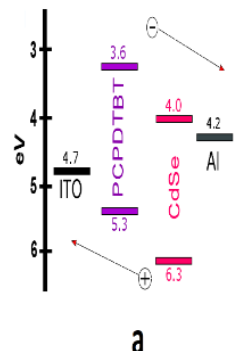

a

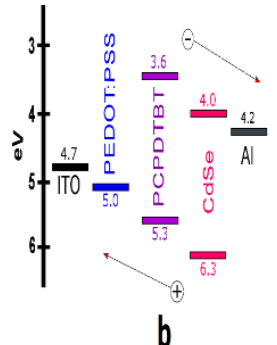

b

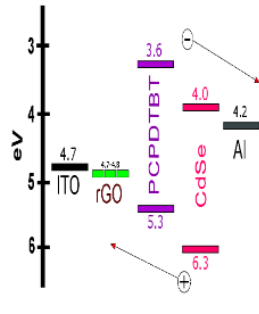

C
Gambar 6 Skematik dari tingkat energi ketiga kelompok divais sel surya.

(a) Tanpa HTL, (b) PEDOT:PSS HTL, and (c) rGO HTL.

Struktur disain (a) mengakibatkan ketidakcocokan level pada sistem transport lubang, sehingga akan mempromosikan terjadinya akumulasi muatan pada antarmuka semikonduktor dan polimer. Mobiltas lubang menjadi terganggu, menghasilkan transport lubang ke anoda menjadi sangat minim dan berakhir pada terjadinya rekombinasi. Sehingga dapat disimpulkan bahwa sistem transport lubang menggunakan rGO and PEDOT:PSS lebih disukai. 


\section{Simpulan}

Penggunan GO berbasis larutan diikuti reduksi termal pada sel surya hibrid bulk-heterejunction telah mampu memberikan efisiensi yang tinggi sebesar $1,7 \%$ jika dibandingkan tanpa HTL yang hanya menunjukkan $0,1 \%$. Hal ini menunjukan potensi yang besar untuk digunakan sebagai alternatif PEDOT:PSS pada aplikasi HTL. Penelitian lebih lanjut dapat dilakukan dengan menginvestigasi pengaruh derajat reduksi terhadap efisiensi.

\section{Kepustakaan}

[1] Jonda, C., et al., Surface roughness effects and their influence on the degradation of organic light emitting devices. Journal of Materials Science, 2000. 35(22): p. 5645-5651.

[2] Jong, M.P.d., L.J. van IJzendoorn, and M.J.A. de Voigt, Stability of the interface between indium-tin-oxide and poly(3,4ethylenedioxythiophene)/poly(styrenesulfonate) in polymer lightemitting diodes. Applied Physics Letters, 2000. 77(14): p. 22552257.

[3] Wong, K.W., et al., Blocking reactions between indium-tin oxide and poly (3,4-ethylene dioxythiophene):poly(styrene sulphonate) with a self-assembly monolayer. Applied Physics Letters, 2002. 80(15): p. 2788-2790.

[4] Kim, Y.-H., et al., Performance and stability of electroluminescent device with self-assembled layers of poly(3,4ethylenedioxythiophene)-poly(styrenesulfonate) and polyelectrolytes. Thin Solid Films, 2006. 510(1-2): p. 305-310.

[5] Norrman, K., et al., Degradation Patterns in Water and Oxygen of an Inverted Polymer Solar Cell: Journal of the American Chemical Society. J. Am. Chem. Soc., 2010. 132(47): p. 16883-16892.

[6] Winter, I., et al., The thermal ageing of poly(3,4ethylenedioxythiophene). An investigation by $X$-ray absorption and $X$ ray photoelectron spectroscopy. Chemical Physics, 1995. 194(1): $\mathrm{p}$. 207-213.

[7] Guillén, C. and J. Herrero, High-Performance Electrodes for Organic Photovoltaics, in Organic Photovoltaics. 2009, Wiley-VCH Verlag GmbH \& Co. KGaA. p. 399-423.

[8] Züfle, S., et al., An Effective Area Approach to Model Lateral Degradation in Organic Solar Cells. Advanced Energy Materials, 2015. 5(20): p. 1500835-n/a.
[9] Huang, L.-C., et al., Self-assembled multilayers of modified ITO in polymer solar cells by soft-imprinting. Soft Matter, 2012. 8(5): p. 1467-1472.

[10] Gao, Y., et al., Anode modification of inverted polymer solar cells using graphene oxide. Applied Physics Letters, 2010. 97(20): p. 203306.

[11] Chang, D.W., et al., Graphene in photovoltaic applications: organic photovoltaic cells (OPVs) and dye-sensitized solar cells (DSSCs). J. Mater. Chem. A, 2014. 2(31): p. 12136-12149.

[12] Wang, X., L. Zhi, and K. Müllen, Transparent, Conductive Graphene Electrodes for Dye-Sensitized Solar Cells. Nano Lett, 2008. 8(1): p. 323-327.

[13] Eda, G., G. Fanchini, and M. Chhowalla, Large-area ultrathin films of reduced graphene oxide as a transparent and flexible electronic material. Nat Nano, 2008. 3(5): p. 270-274.

[14] Liu, J., M. Durstock, and L. Dai, Graphene oxide derivatives as holeand electron-extraction layers for high-performance polymer solar cells. Energy Environ. Sci., 2014. 7(4): p. 1297-1306.

[15] Dreyer, D.R., et al., The chemistry of graphene oxide. Chem. Soc. Rev., 2010. 39(1): p. 228-240.

[16] Mao, S., H. Pu, and J. Chen, Graphene oxide and its reduction: modeling and experimental progress. RSC Adv, 2012. 2(7): p. $2643-$ 2662.

[17] Nair, R.R., et al., Fine Structure Constant Defines Visual Transparency of Graphene. Science, 2008. 320(5881): p. 1308.

[18] Balasubramanian, N. and A. Subrahmanyam, Studies on Evaporated Indium Tin Oxide (ITO)/Silicon Junctions and an Estimation of ITO Work Function. Journal of The Electrochemical Society, 1991. 138(1): p. 322-324.

[19] Mühlbacher, D., et al., High Photovoltaic Performance of a LowBandgap Polymer. Advanced Materials, 2006. 18(21): p. 2884-2889.

[20] Scharber, M.C., et al., Design Rules for Donors in BulkHeterojunction Solar Cells-Towards 10\% Energy-Conversion Efficiency. Advanced Materials, 2006. 18(6): p. 789-794.

[21] Querner, C., et al., Size and ligand effects on the electrochemical and spectroelectrochemical responses of CdSe nanocrystals. Phys. Chem. Chem. Phys., 2005. 7(17): p. 3204-3209.

[22] Wu, R., et al., Control of the oxidation level of graphene oxide for high efficiency polymer solar cells. RSC Adv, 2015. 5(61): p. 4918249187.

[23] Sygellou, L., et al., Work Function Tuning of Reduced Graphene Oxide Thin Films. J. Phys. Chem. C, 2016. 120(1): p. 281-290. 